\title{
Przedmioty niezwykłe i typowe w osiemnastowiecznych spisach mobiliów. Inwentarz ruchomości podkomorzego wschowskiego Ignacego Nieżychowskiego ${ }^{1}$
}

Badania nowożytnych inwentarzy szlacheckich pozwalają określić status materialny i społeczny posiadaczy spisanych przedmiotów. Jednak na tym ich rola się nie kończy. Zebrane $w$ inwentarzu mobilia dają nieraz możliwość zdobycia wielu innych informacji o właścicielu. Często będą to wiadomości o jego przyzwyczajeniach, zainteresowaniach, horyzontach myślowych, aspiracjach, a czasem nawet o światopoglądzie. Inwentarz jest spisem przedmiotów, w którym, niczym w lustrze, odbija się postać człowieka sprzed wieków. Daje możliwość poznania kultury materialnej, w której przedmioty miały inną wartość niż obecnie. Oprócz wartości czysto użytkowej i materialnej miały także znaczenie symboliczne, tym bardziej, że dziedziczono je po przodkach i pozostawiano je następnym poko. leniom, co potwierdzało ciągłość rodu, jego tradycję i status społeczny ${ }^{2}$. W odróżnieniu od tej sytuacji, obecnie to my jesteśmy świadkami narodzin i śmierci przedmiotów $w^{3}$.

Istnieją różne metody badania kultury materialnej na podstawie spisów mobiliów ${ }^{4}$. Zawarte $w$ nich informacje można interpretować przez pryzmat wartości ruchomości i w ten sposób ocenić zamożność właściciela. Jednak takie podejście nie wyczerpuje tematu. Każdy przedmiot, oprócz wartości materialnej, miał też przypisane mu znaczenie ( $\mathrm{z}$ czasem ulegające zmianom), i mógł służyć do demonstrowania okreslonej postawy, a także pozycji społecznej ${ }^{5}$.

${ }^{1}$ Artykuł jest zmienioną wersją mojej pracy, napisanej na proseminarium dr J. Dumanowskiego.

${ }^{2}$ J. Dumanowski, Inwentarze wielmożnych $i$ urodzonych. Konsumpcja szlachty wielkopolskiej w XVIII wieku, [w:] Kwartalnik Historii Kultury Materialnej K. LI: 2003, z. 2, s. 262, 269-270.

${ }^{3}$ J. Baudrillard, Spoleczeństwo konsumpcyjne. Jego mity i struktury, Warszawa 2006, s. 8.

4 Przykładami takich studiów są prace: J. Dumanowski, Świat rzeczy szlachty wielkopolskiej w XVIII wieku, Toruń 2006; E. Kowecka, W salonie i kuchni. Opowieść o kulturze materialnej pałaców i dworów polskich w XIX w, Warszawa 1984; A. Pośpiech, Pulapka aczywistości. Pośmiertne spisy ruchomości szlachty wielkopolskiej z XVII wieku, Warszawa 1992.

${ }^{5}$ J. Dumanowski, Inwentarze wielmożnych..., s. 261-262. 


\section{IGNACY NIEŻYCHOWSKI I JEGO DZIAEALNOŚĆ POLITYCZNA}

Ignacy Nieżychowski herbu Pomian był synem Andrzeja Nieżychowskiego oraz Ludwiki Gurowskiej herbu Wczele, kasztelanki poznańskiej. Jego ojciec (a następnie Ignacy) był dziedzicem na majątkach w Sędzinie, Sędzinku (oba majątki w powiecie szamotulskim), Zakrzewie, Książu, Radoszkowie, Kiełczynie (w pow. śremskim), Trzebini, Długim Starym (Wielkim) i Dlugim Małym (ostatnie trzy w pow. wschowskim) $)^{6}$. Fakt posiadania aż dziewięciu majątków w Wielkopolsce świadczy o przynależności do warstwy zamożnej szlachty'. Starszy brat Ignacego, Józef, zmarł w 1741 r. i został pochowany razem $z$ ojcem na cmentarzu przy kościele w Długim Starym. Ignacy odziedziczył dobra po ojcu i bracie. Ożenił się z Ludwiką, córką Mikołaja Jabłonowskiego herbu Prus, łowczego trembowolskiego, pułkownika wojsk koronnych i sekretarza poselstwa do Turcji ${ }^{8}$. Ludwika urodziła syna Adama, który uzyskał godność na dworze Stanisława Augusta. Został szambelanem królewskim (tytuł nadawany jako wyróżnienie, wiązał się $z$ pełnieniem dyżurów przy królu) ${ }^{9}$. Inwentarz wspomina ponad to o „córce młodszej"'10 (a więc musiała być i starsza) oraz o dwóch kolejnych synach Antonim i Andrzeju ${ }^{11}$, ich dalsze losy nie są jednak znane.

Wróćmy jednak do Ignacego Nieżychowskiego. Nie wiemy, jakie uzyskał wykształcenie, ani gdzie spędził młodość. Więcej można powiedzieć o jego działalności publicznej. Był on aktywnym politykiem szlacheckim. W latach pięćdziesiątych XVIII wieku związał się z ugrupowaniem Jerzego Augusta Mniszcha, marszałka nadwornego koronnego. Działalność tego obozu politycznego miała na celu wspieranie króla Augusta III Sasa, a tym samym unii polsko-saskiej, a także zapewnienie tronu jego synowi. Mniszech, od 1757 r. związany z Wielkopolską (pełnił urząd starosty generalnego wielkopolskiego), starał się uzyskać wpływ na elekcje urzędników ziemskich, w tym podkomorzych ${ }^{12}$. Podkomorzego mianował

${ }^{6}$ Stownik Geograficzny Królestwa Polskiego i innych krajów stowiańskich, pod red. B. Chlebowskiego i W. Walewskiego, T. II, Warszawa 1881, s. 37; T. IV, Warszawa 1883, s. 39, 826; T. IX, Warszawa 1888, s. 440; T. X, Warszawa 1989, s. 465 466; T. XII, Warszawa 1892, s. 558; T. XIV, Warszawa 1895, s. 320; M. Libicki, P. Libicki, Dwory i palace wiejskie w Wielkopolsce, Poznań 2003, s. 82; T. Żychliński, Zlota księga szlachty polskiej, T. XI, Poznań 1889, s. 121.

${ }^{7}$ A. Pośpiech, Majatek osobisty szlachcica w świetle wielkopolskich pośmiertnych inwentarzy ruchomości z XVII wieku, [w:] Kwartalnik Historii Kultury Materialnej, R. XXIX: 1981, ar 4, passim; tenże, Pulapka oczywistósci..., s. 40.

${ }^{8}$ A. Boniecki, Herbarz polski, Część I, Wiadomości historyczno-gentealogiczne o rodach szlacheckich, T. VIII, Warszawa 1905, s. 115; Katalog zabytków sztuki w Polsce, T. V: województwo poznańskie, z. 12: powiat leszczyńsid, Warszawa 1975, s. 4-5; K. Niesiecki, Herbarz polski, T. IV, Lipsk 1839, s. 416; T. Zychliński, Zlota księga... s. 121-122.

${ }^{9}$ Z. Góralski, Encyklopedia urzędów i godności w dawnej Polsce, Warszawa 2000, s. 155-156; T. Żychliński, Zlota ksiega..., s. 122.

${ }^{10}$ Archiwum Państwowe w Poznaniu, Wschowa, grodzkie, 224, k. 475 (cyt. dalej: APP, Wschowa, gr. 224).

"APP, Wschowa, gr. 224, k. 479.

${ }^{12}$ M. Czeppe, Kamaryla Pana z Dukli. Ksztaltowanie się obozu politycznego Jerzego Augusta Mniszcha 1750-1763, Warszawa 1998, s. 7, 152. 
król, mając do dyspozycji czterech kandydatów, wybranych przez szlachtę na sejmiku' ${ }^{13}$. Jak już wspomniałem, Nieżychowski należał do „partii” dworskiej i stał się protegowanym Mniszcha. W 1758 roku, dzięki jego poparciu, uzyskał urząd podkomorzego wschowskiego ${ }^{14}$. Trzeba tu zaznaczyć, że podkomorzy, jako najwyższy urzędnik ziemski, cieszył się dużym prestiżem wśród szlachty. Uzyskana przez Nieżychowskiego godność świadczy o tym, że musiał być jednym ze znaczniejszych szlacheckich stronników Mniszcha w Wielkopolsce. W latach 1759-1763, w okresie szczytowej działalności ugrupowania, wymienił z nim 10 listów. Z czasem wpływy Mniszcha malały za sprawą niezadowolenia szlachty. Śmierć króla Augusta III i wybór na jego następcę Stanisława Augusta, przy poparciu Rosji, spowodowaly upadek stronnictwa związanego $\mathrm{z}$ dynastią wettyńską ${ }^{15}$.

Ziemia Wschowska, znajdująca się na pograniczu Wielkopolski i Śląska, była odmienna od pozostałych ziem Polski przedrozbiorowej pod względem ustroju. Ponadto bliskość Śląska oraz szlak łączący Drezno z Warszawą sprawiały, że region ten znajdował się $w$ XVIII wieku pod wplywem kultury niemieckiej. Położenie na szlaku między dwiema stolicami (Saksonii i Rzeczypospolitej) było z pewnością nobilitujące dla miasta i okolicy. Jego ranga wzrosła za sprawą przejazdów króla. Nie bez znaczenia dla jego rozwoju był również handel. Ziemia Wschowska, podobnie jak cała Wielkopolska, należała wówczas do najbogatszych obszarów Polski ${ }^{16}$.

Okres najintensywniejszej działalności politycznej Nieżychowskiego wiąże się $\mathrm{z}$ wojną siedmioletnią (1757-1763), w czasie której Rzeczpospolita, niezaangażowana w same walki, była grabiona przez obce wojska. W 1759 roku dwukrotnie obrabowany został również mieszkający na pograniczu Nieżychowski, najpierw przez kozaków, następnie przez austriackich huzarów, tracąc część majątku i odnosząc przy tym rany ${ }^{17}$. Na tym kończą się informacje o działalności Nieżychowskiego. W czasie konfederacji barskiej (1768-1772) prawdopodobnie nie odgrywał już większej roli politycznej w regionie. Wiadomo, że Nieżychowski pełnił urząd podkomorzego wschowskiego przez 20 lat ${ }^{18}$, do rezygnacji, która nastąpila przed 18 czerwca $1778 \mathrm{r}$. Zmarł trzy miesiące później, 22 września $1778 \mathrm{r}^{19}$

${ }^{13} \mathrm{~S}$. Płaza, Historia prawa w Polsce na tle porównawczym, cz. I: X-XVIII w., Kraków 1997, s. 537.

${ }^{14}$ M. Czeppe, Kamaryla Pana..., s. 154; Urzednicy wielkopolscy XVI-XVIII wieku. Spisy, oprac. A. Bieniaszewski, Wrocław-Warszawa-Kraków-Gdaŕsk-Lódz 1987 (T. I, z. 2 serii: Urzędnicy dawnej Rzeczypospolitej XII-XVIII wieku, pod red. A. Gąsiorowskiego), s. 220.

${ }^{15}$ M. Czeppe, Kamaryla Pana..., s. 56, 242, 269; J. Gierowski, Historia Polski 1764-1864, Warszawa 1984, s. 62.

${ }^{16}$ Dzieje Wielkopolski, T. I do roku 1793, pod red. J. Topolskiego, Poznań 1969, s. 848-849; J. Topolski, Wielkopolska poprzez wieki, Poznań 1999, s. 130; A. Nowakowski, Wschowa i Ziemia Wschowska w dawnej Polsce (do roku 1793), Białystok 1994, s. 49.

${ }^{17}$ M. Czeppe, Wojna i pokój w „karczmie zajezdnej". Z dziejów wojny siedmioletriej, [w:] Między Barokiem a Oświeceniem. Wojny i niepokoje czasów saskich, pod red. K. Stasiewicza i S, Achremczyka, Olsztyn 2004, s. 29-30.

: Urząd podkomorzego był pelniony dożywotnio, por. S. Plaza, Historia prawa..., \$. 537.

'S Urzędnicy wielkopolscy..., s. 177-178, 220. 
O katolickim wyznaniu Ignacego Nieżychowskiego świadczy fakt, że zapisał na swoich dobrach w 1760 r. roczny procent od $20000 \mathrm{zt}$ jezuickiemu kolegium w Poznaniu. Możemy przypuszczać, że był jego wychowankiem, Iub jeden z jego synów zdobył w nim wykształcenie. Podobny gest wykonała jego małżonka, odnawiając w 1769 r. katolicki kościół parafialny p.w. św. Marcina w Długim Starym. Dzięki temu został on rozbudowany i zyskał wyposażenie ${ }^{20}$. W powszechnej opinii obdarowywanie duchowieństwa i Kościoła katolickiego należało w tym czasie do podstawowych powinności szlachcica-katolika. Byla to jedna $z$ możliwości demonstrowania wiary i pobożności lub okazywania wdzięczności wobec szkół jezuickich za uzyskane wykształcenie ${ }^{21}$. Pośmiertny inwentarz opisujący ruchomości, a pośrednio także i nieruchomości, daje nam możliwość poznania jego majątku, a pośrednio stylu i standardu życia ${ }^{22}$.

\section{OKOLICZNOSCI SPORZAZDZENIA INWENTARZA}

Pośmiertny rejestr ruchomości ${ }^{23}$ będący podstawą pracy, został spisany po śmierci Ignacego Nieżychowskiego, przez wdowę Ludwikę Nieżychowską dnia 29 października $1778 \mathrm{r}^{24}$ (ponad pięć tygodni po śmierci). Nastąiło to w czasie zjazdu sądu $w$ jego domu ${ }^{25}$, $\mathrm{z}$ udziałem wierzycieli i sukcesorów. Inwentarz składa się z czterech części. Pierwsza $z$ nich wymienia ruchomości znajdujące się na terenie dworu w Długim Starym, w dośc nietypowym układzie, z podziałem na izby. Druga część to spis ubrań i bielizny. Trzecia jest spisem rzeczy osobistych oraz rzeczy znajdujących się we Wschowie. Czwartą część stanowią inwentarze zwierząt i przedmiotów znajdujących się w folwarkach, m.in. w Długim Starym i Długim Małym. Najwięcej uwagi chciałbym poświęcić temu, co w spisie tych mobiliów jest nietypowe, a nieraz zaskakujące, na tle dość powszechnie spotykanych przedmiotów.

\section{DWÓR}

Pierwsza część inwentarza wymienia ruchomości znajdujące się $w$ dworze w Dlugich Starych z podziałem na poszczególne pomieszczenia. Ten nieczęsto spotykany układ pozwala nam określić wielkość siedziby oraz poznać funkcje po-

${ }^{20}$ Katalog zabytków..., s. 3; T. Żychliński, Zlota księga ..., s. 122.

${ }^{21}$ J. St. Bystroń, Dzieje obyczajów w dawnej Polsce. Wiek XVI-XVIII, Warszawa 1960, T. I, s. 317, 331; J. Tazbir, Kultura szlachecka w Polsce. Rozkwit - upadek - relikty, Warszawa 1978, s. 120-121.

${ }^{22}$ A. Pośpiech, Srebrna lyżka - probierz szlacheckiej zamożności? (Przyklad Wielkopolski XVII wieku), [w:] Nędza i dostatek na ziemiach polskich od średniosiecza po XX wiek, pod red. J. Sztetylły, Warszawa 1992, s. 152.

${ }^{23}$ APP, Wschowa, gr. 224 , k. 469 v. -473 v., $474-475,476 \cdots 481$ v., $482-483$.

${ }^{24}$ Ibidem, k. 470, 476, Jeden z podpisów nosi też datę 6 listopada 1778 r., co może być datą oblaty. Por. APP, Wschowa, gr. 224, k. 481.

${ }^{25}$ Inwentarz podaje: w trakcie kondescensji (APP, Wschowa, gr. 224, k. 470), termin „kondescerısja" oznaczał zjazd sądu na grunt dóbr, jakich gdzie kontrowersya zaszła (S. B. Linde, Stownik języka polskiego, T. II, Lwów 1855, s. 54. 
szczególnych izb, co może być przyczynkiem do opisu nie tylko ruchomości, ale również samego dworu Nieżychowskiego. Rejestr wymienia dwanaście pomieszczeń. Pierwsze $z$ nich to sień, czyli pierwsze pomieszczenie, prowadzące do wnętrza dworu. W sieni znajdowaly się schody (zapewne prowadzące na poddasze), szafy i skrzynie do przechowywania różnych rzeczy, latarnia, magiel i osobliwość - lektyka służąca do noszenia wdowy do kościoła ${ }^{26}$. Trzy pierwsze pokoje miały charakter reprezentacyjny. W nich znajdowały się obicia, kobierce, firanki, meble (szafy, komody, krzesła, stoły), obrazy. Byly to najbardziej „zagracone” izby, slużyły zapewne do podejmowania gości ${ }^{27}$. W tych pomieszczeniach zbierala się rodzina oraz podawano posiłki ${ }^{28}$. W czwartym pokoju sprzętów jest już o wiele mniej. Nie ma obić, kobierców ani obrazów, a jak wynika ze spisu, część sprzętów jest uszkodzona ${ }^{29}$. Piąty pokój opisany jako „poboczni” jest za to zdominowany przez obrazy (religijne, rodzinne, „landszafty”) oraz przez kopersztychy ${ }^{30}$. Z tego pokoju przechodzilo się do gabinetu, pełniącego rolę garderoby. Znajdowały się w nim meble przeznaczone do przechowywania bielizny małżonków ${ }^{31}$. Stąd można było przejść do apteczki, którą wypełniały "flaszki”, „słoiki”, „faseczki”, „pudełka" ${ }^{32}$. Apteczka była pomieszczeniem w którym przechowywano lekarstwa i specjały kuchenne (wódki, słodycze, przyprawy, korzenie) na użytek domowników, a nieraz i ludności wiejskiej ${ }^{33}$. Kolejne pomieszczenie to „izba służna w tyłach". Jest ona ubogo wyposażona (piec, kilka ław i stołków), spała tam służba, a ponadto wypiekano tam chleb ${ }^{34}$. W kuchni znajdowało się dużo (prawie 50 sztuk) różnych naczyń i garnków miedzianych, mosiężnych i żelaznych, w tym kocioł ${ }^{35}$. Spiżarnia służyła do przechowywania żywności, były tam cynowe naczynia, skrzynia, śruba do peklowania mięsa i mlynek do pieprzu ${ }^{36}$. Ostatnim pomieszczeniem była izba gościnna, ubogo wyposażona tylko w stołki i dwie szafki ${ }^{37}$. Skromne wyposażenie pokoi gościnnych oraz tych przeznaczonych dla służby nie jest sytuacją wyjątkową, gdyż o te izby zwykle dbano najmniej ${ }^{38}$. Trzy pierwsze izby, jako pomieszczenia reprezentatywne, byly najlepiej wyposażone. To właśnie w nich znajdowało się najwięcej sprzętów i ozdób, świadczących o zamożności gospodarza. Tam też koncentrowało się życie rodziny. Natomiast w pozostalych izbach przedmiotów było znacznie mniej, a rejestr sugeruje, że niektóre z nich byly stare lub zniszczone.

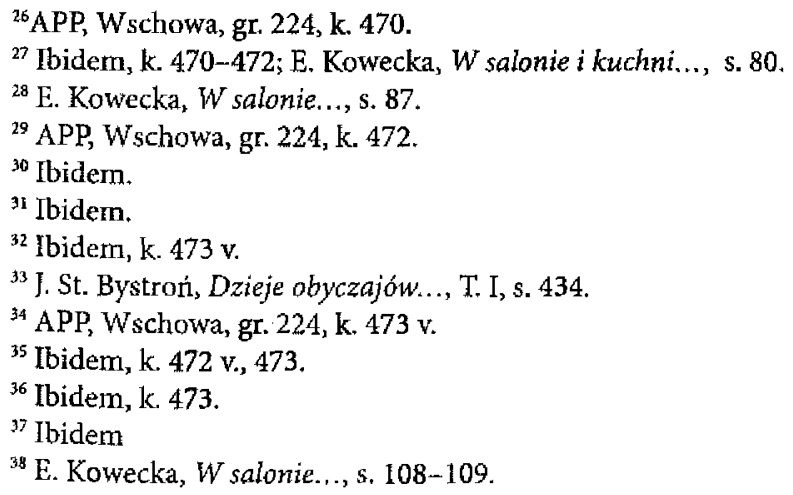




\section{OBRAZY}

W niemal każdym pomieszczeniu reprezentacyjnym znajdowały się obrazy. W inwentarzach z XVIII wieku są to przedmioty niezbyt często spotykane, dlatego poświecę im więcej miejsca. Podzieliłem je na trzy kategorie. Pierwsza obejmuje obrazy religijne, przedstawiające świętych i postacie biblijne. W poszczególnych pokojach odnajdujemy piętnaście takich obrazów. Przedstawiają one Jezusa, Maryję, świętych: Józefa, Nepomucena, Ksawerego, Cecylię, Ludwikę, Czterech św. Doktorów Kościoła i sceny biblijne ${ }^{39}$. Świętym przypisywano określone funkcje i role. I tak święty Nepomucen pomagał bronić dobrej sławy, a święty Ksawery byl czczony jako patron jezuitów $w^{40}$. Oczywiste jest, że posiadanie obrazów świętych potwierdza katolickie wyznanie ich właścicieli. Do przedmiotów związanych $z$ kultem religijnym należy także relikwiarz wdowy i drewniany krzyżyk oraz krucyfiks ${ }^{41}$. Druga kategoria to obrazy przedstawiające rodzinę i przodków, których nie mogło zabraknąć u żadnego szlachcica dbającego o tradycję rodzinnąa ${ }^{42}$. Nieżychowski posiadał dwadzieścia takich obrazów. Przedstawiały one całą familię lub poszczególnych członków rodziny, między innymi wdowę i Stanisława Karola Jabłonowskiego, starostę bohusławskiego i oboźnego koronnego, zmarłego w 1702 lub 1703 roku $^{43}$. Przedstawieniu przodków musiala służyć również „iluminowana genealogia"44. Ostatnia kategoria zawiera obrazy świeckie, przedstawiające mityczne sceny, krajobrazy i portrety władców $w^{45}$. Było ich około trzydziestu, przedstawiały królów polskich, a co ciekawe, na jednym $\mathrm{z}$ nich widniał wizerunek króla pruskiego ${ }^{46}$, krajobrazy ("landszafty”), osoby (staruszek, pasterz) oraz postacie mityczne (m.in. Lukrecja) ${ }^{47}$.

Zaskakująca jest liczba kopersztychów czyli miedziorytów i rycin ${ }^{48}$. W jednym tylko pokoju było ich aż 168 (!), na kolejnych stronach inwentarza wymienionych jest ich ponad 300. Niektóre $z$ nich są określane jako oprawne, lub iluminowane. Zawierały nawet francuskie wiersze ${ }^{49}$. $\mathrm{O}$ ile pierwsze kategorie stanowią umiarkowany (jak na zamożnego szlachcica) zbiór kilkudziesięciu obrazów, to ilość kopersztychów jest ogromna i świadczy o zamożności ich wlaściciela.

${ }^{39}$ APP, Wschowa, gr. 224, k. 471-472.

40 J. St. Bystroń, Dzieje obyczajów..., T. I, s. 305 307; J. Hall, Leksykon symboli sztuki Wschodu i Zachodu, Kraków 1997, s. 268-269.

${ }^{41}$ APP, Wschowa, gr. 224, k. 471-479.

${ }^{42} \mathrm{~J}$. St. Bystroń, Dzieje obyczajów..., T. II, s. 407.

${ }^{43}$ APP, Wschowa, gr. 224, k. 470-472; Urzędnicy centralni i nadworni Polski XIV-XVIII wieku. Spisy, pod red. A. Gąsiorowskiego, Kórnik 1992, s. 171.

${ }_{44}^{4}$ APP, Wschowa, gr. 224, k. 477.

${ }^{45}$ J. St. Bystroń, Dzieje obyczajów..., T. II, s. 409-410.

${ }^{46}$ Nieżychowski nie posiadał dóbr położonych w Prusach (tzn. poza granicami Rzeczypospolitej) a ponadto należał do stronnictwa Mniszcha, więc znalezienie w inwentarzu portretu króla pruskiego może być nieco zaskakujące.

${ }^{47}$ APP, Wschowa, gr. 224, k. 470-472, 476.

${ }^{4 B}$ Slownik wyrazów obcych PWN, pod red. J. Tokarskiego, Warszawa b.d.w., s. 390.

${ }^{49}$ APP, Wschowa, gr. 224, k. 472, 476-477, 480 . 


\section{UBRANIA I BRON}

Drugą część inwentarza stanowi spis odzieży, bielizny i broni50. Do bielizny zaliczono koszule (tych było aż 33), ręczniki, chustki do nosa (23 sztuki), pończochy niciane oraz obrusy, serwety, pościel i pawilony. Na ubrania wierzchnie Nieżychowskiego składały się: suknia oliwkowa $\mathrm{z}$ sukna holenderskiego $\mathrm{z}$ kamizelką i innymi ubiorami do niej, dwie suknie "półsukienkowe", jedna cynamonowa, druga popielata, również z kamizelkami i ubiorami. $Z$ pewnością były to najcenniejsze stroje, zostały bowiem wymienione jako pierwsze pozycje spisu. Ponadto było jeszcze pięć kamizelek, ubiór „szarzydrenowy”, cycowy, trzy ubiory płócienne, dwie czapki sukienne $\mathrm{z}$ barankiem i dwie pary butów zamszowych. Nieżychowski używał dwóch szlafroków plóciennych, co ciekawe, jeden określony jako niemiecki, drugi polski, oba podszyte "królikami czarnymi” i z kołnierzami ze „swojskich kun". W XVIII wieku suknie były wierzchnim okryciem, wykonywanym według mody francuskiej ${ }^{51}$. Noszono je razem $z$ kamizelką i pończochami, które także odnajdujemy w rejestrze. Uzupełnieniem tego stroju była „laska dębowa $z$ gałką dębową" ${ }^{22}$. Spis nie wymienia żadnych ubrań składających się na polski strój narodowy, tzn. żupana i kontusza. Nieżychowski ubierał się według wzorców zachodnich. W drugiej połowie XVIII wieku szlachta polska odchodziła od mody kontuszowej. Szlachta zamożna, mająca kontakty $z$ dworem drezdeńskim i często podróżująca (do takich osób zaliczał się Ignacy Nieżychowski) ulegała modzie zachodniej i przyjmowała strój francuski, nazywany w Polsce nieraz niemieckim $^{53}$. Także szlafrok, ubiór domowy ma zachodnie (niemieckie) pochodzenie, lub przynajmniej za taki był uważany ${ }^{54}$.

Uzupełnieniem stroju była broń. Inwentarz wymienia nieduży jej zbiór; pięć pistoletów, skórzany, czarny flintpas (pas do strzelby), pas do kordelasa (krótkiej białej broni myśliwskiej ${ }^{55}$ ), zielony pendent do kordelasa $z$ zamkiem i spinką ${ }^{56}$. W inwentarzu znalazly się także: „mała trzcinka mosiężna do nabijania pistoletów", "worki skórzane do śrutu” i "rogi do prochu"s7. Broń ta zapewne była wykorzystywana do polowania, podobnie jak charty. Rejestr wspomina o smyczy do

${ }^{50}$ Ibidem, k. 474-475.

${ }^{51}$ I. Turnau, Slownik ubiorów. Tkaniny, wyroby pozatkackie, skóry broń i klejnoty oraz barwy znane w Polsce od średniowiecza do początku XIX w., Warszawa 1999, s. 171.

52 APP, Wschowa, gr. 224, k. $478 \mathrm{v}$.

${ }^{53}$ M. Gutkowska-Rychlewska, Historia ubiorów, Wroclaw-Warszawa-Kraków 1968, s. $579-$ $-581,584-585,655,667$; J. Kitowicz, Opis obyczajów za panowania Augusta III, Warszawa 1985, s. 247-248; A. Pośpiech, Pulapka oczywistości..., s. 105; I. Turnau, Rozwój ubioru narodowego od około 1530 do 1795 roku, [w:] Kwartalnik Historii Kultury Materialnej, R. XXXIV: 1986, nr 3, s. 417, 421; A. Urbaniak, Ubiór szlachty polskiej w czasach stanislawowskich w opinii wspólczesnych, [w:] Kwartalnik Historii Kultury Materialnej, R. XXXIV: 1986, nr 3, s. 464-465.

${ }^{54}$ I. Turnau, Stownik ubiorów..., s. 177.

${ }^{55}$ Ibidem, s. 57, 93.

${ }^{56}$ APP, Wschowa, gr. 224, k. 475, 478-479, Pendent to pas od szpady, por. S. B. Linde, Słownik jezzka polskiego, T. IV, Lwów 1858 , s. 76-77.

${ }^{57}$ APP, Wschowa, gr. 224, k. 478 v. 
chartów i trzech obrożach dla nich. Posiadanie chartów było kosztownym wydatkiem, w XVIII wieku nie każdy szlachcic mógł sobie na to pozwolić. Znamienne: że $w$ inwentarzu nie wymieniono wśród broni białej szabli. Była ona elementem polskiego stroju narodowego, który, jak już wiemy, nie cieszył się specjalną estymą Nieżychowskiego. $O$ tym, jak była cenna i jak długo, nieraz przez kilka pokoleń, noszona odzież w XVIII wieku świadczy fakt, że synowie Ignacego używali dwóch jego czapek i jednej pary butów ${ }^{58}$.

\section{MAPY I KSIAZZKI}

Uwagę zwraca duża ilość map i atlasów, stanowiących prawdziwy unikat w spisach ruchomości $z$ tego okresu ${ }^{59}$. Niestety, inwentarz nie wymienia ich tytufów, lecz jedynie liczbę. Atlasy były cztery, jeden określony jako oprawny, inny jako mały. Każdy z nich zawierał kilkadziesiąt, a nawet sto map. Ponadto, poza atlasami znajdowały się mapy w futerale, jedna $\mathrm{z}$ nich została opisana jako "mapa długa w której batalie różne oznaczone"60. Razem map (łącznie ze znajdującymi się w atlasach) było aż 225 . Tak wielka ich liczba sugeruje zainteresowania strategią i historią, geografią, podróżami i dalekimi krajami. Pozwala to również wnosić o majętności ich właściciela.

Dokładniejszych informacji dostarcza nam inwentarz na temat całkiem pokaźnego zbioru książek. Zanotowano w nim 36 tytułów w 46 tomach ${ }^{61}$, podając liczbę tomów i język, w którym książka została napisana. Na ogół pominięto natomiast autora, a we wszystkich wypadkach datę i miejsce wydania ${ }^{62}$. Tytuły można podzielić na kilka podstawowych kategorii. Pierwsza obejmuje książki religijne, są to: dwie Biblie ${ }^{63}$, „Pasja Zbawiciela Jezusa” ${ }^{\text {, }}$, „Opisanie Sławnej Męki Panny Maryi"65. Druga najliczniejsza grupa zawiera książki związane z polityką i prawem, a więc przydatne urzędnikowi ziemskiemu i politykowi szlacheckiemu. Można do nich zaliczyć sześć tomów „Volumina legum”, czyli wydany przez pijarów zbiór

${ }^{58}$ APP, Wschowa, gr. 224, k. 479.

${ }^{59}$ Ibidem, k. 477.

${ }^{60} \mathrm{Ibidem}$.

${ }^{61}$ Ibidem, k. 477-478.

${ }^{62}$ Zapisy w inwentarzach odnoszące się do książek rzadko podawały pełne tytuły razem $z$ autorem, miejscem i datą wydania. Od tego schematu nie odbiega inwentarz Nieżychowskiego, por. P. Buchwald-Pelcowa, Inwentarz biblioteki Macieja Grabskiego (z zagadnień czytelnictwa w drugiej potowie XVII w.), [w:] Rocznik Biblioteki Narodowej, R. 2: 1966, s. 319.

${ }^{63}$ APP, Wschowa, gr. 224, k. 477.

${ }^{64}$ Ibidem, Chodzi prawdopodobnie o jeden $z$ dwóch następujących tytułów: Pasja Passya albo historya męki Pana y Zbawiciela naszego Jezusa Chrystusa. Pasja wedlug 4 Ewangelistów kolejno, urywek z większego dzieła: Pasja wedlug 4 Ewangelistów kolejno lub o: Bourdaloue, Louis, Męka Zbawiciela naszego Chrystusa Jezusa $w$ dziesięciu przednieyszych taiemnicach swoich postnemi exhortami przez [...] Ludwika Bourdaloue [...] przeloziona, teraz polskim jezykiem z francuskiego do czytania i [...] rozważenia podana przez X. Jerzego Devina [...]. Kalisz Druk. J. K. M. Colleg. Soc. Jesu 1769; Por. Katalog Biblioteki Kórnickiej dostępny w Internecie: http:/www.bkpan.poznan.pl.

${ }^{65}$ APP, Wschowa, gr. 224, k. 477 v. 
konstytucji sejmowych ${ }^{66}$, „Inwentarz [przywilejów, listów i dokumentów w archiwum Koronnym]" Macieja Ładowskiego ${ }^{67}$,, Książka in folio niemieckich praw koronnych"68, oraz „Konstytucja zakończenia konfederacji”69 (być może chodzi o konfederację barską). Trzecią wyróżniającą się grupę stanowią książki historyczne, np. „Historia Polonica” Jana Długosza, „Duodecimi cesar”, czyli „Żywoty Cezarów" Swetoniusza ${ }^{70}$, "Opisanie życia króla Herkulesa", „Tragica in folio vertentis belli percici"7l, „Legationis turcico percicie"72 i „Prodomus ad historicam revolutionis percicie" "3. Kilka książek wskazuje na zainteresowania literaturą: „In" stitutiones poëticae"74, „Dzieła ks[ię]cia Eugena"75, oraz dwa dzieła Owidiusza. Do zainteresowań geografią i mapami nawiązuje tytuł książki: „Opisanie podziału Polski" ${ }^{\prime 76}$. Spis uzupełniaja "Nowe Ateny" ${ }^{\prime 7}$, czyli niezbyt udana encyklopedia Benedykta Chmielowskiego ${ }^{78}$. Ostatnią grupę stanowią książki, których tytułów - nie zawsze przecież zgodnych z zapisem w inwentarzu - ani autorów - nie udało się zidentyfikować. Wymienione książki były napisane w trzech językach: łacińskim, polskim i niemieckim. Niektóre z nich - jak można się było spodziewać - zostały odziedziczone po przodkach, jednak „Volumina legum”, „Opisanie podziału Polski” oraz „Nowe Ateny” mógł Nieżychowski nabyć osobiście, jako, że wydano je w latach trzydziestych i czterdziestych XVIII wieku ${ }^{\text {79. }}$. Pozwala to przypuszczać,

${ }^{66}$ Ibidem, k 477, por. J. St. Bystroń, Dzieje obyczajów..., T. II, s. 296.

${ }^{67}$ APP, Wschowa, gr. 224, k. 477; Polski Stownik Biograficzny, T. XVIII, Wrocław-Warszawa-Kraków-Gdańsk 1973, s. 186-187.

${ }^{68}$ A.PP, Wschowa, gr. 224, k. 477.

${ }^{69}$ Ibidem, k. 477 v.

${ }^{70}$ Ibidem, k. 477., por. M. Grant, Dwunastu cezarów, Warszawa 1997, s. 9, 11.

${ }^{71}$ APP, Wschowa, gr. 224, k. 477.

${ }^{72}$ Ibidem, k. 477 v., Tytul brzmi: Compenditum legationis [...] Stanistawa Malachowskiego, wojewody Poznańskiego, od [...] króla [...] y stanów Rzeczypospolitej Polskiey, ad tractandam pacem z Porta Otomańska Deputowanego Commissarza [...] Zebrane przez [...] Andrzeja Gorkowskiego [...], (1699). Por. Katalog Bỉblioteki Kórnickiej dostępny w Internecie: http:/www.bkpan.poznan.pl.

${ }^{73}$ APP, Wschowa, gr. 224, k. 477 v. Chodzi o książkę: Krusiński, Tadeusz Juda, Historia revolutionis Persicae. Authore P. Juda Krusiriski [...] in gratiam Magni Wezyrij Turcice conscripta. [...]. Typis turcicis Constantinopoli impressa [s.n.] 1729 Turcja; por. Katalog Biblioteki Kórnickiej dostępny w Internecie: http://www.bkpan.poznan.pl.

${ }^{7}$ APP, Wschowa, gr. 224, k. 477, Por. K. Estreicher, Bibliografia polska, T. XVIII, stulecie XV-XVIII, Kraków 1901, s. 583.

${ }^{75}$ APP, Wschowa, gr. 224, k. 477 v., Pełen tytul brzmi: Barbier d'Aucour, Jean Sentimens de Cle. ante sur les Entretiens d'Ariste et d'Eugene. [critique des Entretiens de Bouhours Dominique]. Cologne Chez Pierre du Bois 1671, Por. Katalog Biblioteki Kórnickiej dostępny w Internecie:

http://www.bkpan.poznan.pl.

${ }^{76}$ APP, Wschowa, gr. 224, k. 477 v. Chodzi o książkę: Szybiński, Dominik Gabriel (pijar), Atlas dziecinny czyli nowy sposob do nauczenia dzieci geografii [...] zawieraiący doktadnicysze opisanie Polski y Litwy tudzież naukę o sferze [...] z francuskiego przelożony, powiększony y poprawiony przez [...] Dominika [Gabriela] Szybińskiego [...]. Warszawa M. Groell 1772; Por. Katalog Biblioteki Kórnickiej dostępny w Internecie: http://www.bkpan.poznan.pl.

"APP, Wschowa, gr. 224, k. 477.

${ }^{78}$ J. A. Gierowski, Historia Polski 1505-1764, Warszawa 1984, s. 291.

${ }^{79}$ J. St. Bystron, Dzieje obyczajów..., T. II, s. 296; J. A. Gierowski, Historia Polski.., s. 291. 
że właściciel tego zbioru miał rozległe zainteresowania, a k̦siążki nie stanowił jedynie martwych przedmiotów, ale rzeczywiście były czytane. Nie jest to wię przypadkowa kolekcja, lecz materialny dowód, świadczący o szerokich horyzon tach podkomorzego. Liczba niespełna czterdziestu książek nie stanowi wielkiє biblioteki, jednak jest już całkiem pokaźnym i cennym zbiorem, uzupełnionyn przez papierowy kalendarz wieczysty oraz dwa pamiętniki (być może prowadzon, przez Nieżychowskiego ${ }^{80}$.

Zakładanie małych bibliotek i zbieranie książek w drugiej połowie XVII wieku jest jednym $z$ charakterystycznych zjawisk rozpoczynającego się właśni Oświecenia ${ }^{81}$. Jednak, w końcu XVIII wieku, w inwentarzach szlachty wielkopol skiej książki nadal należą do stosunkowo rzadko wzmiankowanych przedmio. tów. Według J. Dumanowskiego pojawiają się w zaledwie $18 \%$ spisów ${ }^{22}$. Tytuły książek wskazują na pewne zainteresowania polityczne, prawnicze, historyczne a w mniejszym stopniu religijne. Na tej podstawie można też przypuszczać, że ich wlaściciel znał lacinę i język niemiecki. Fakt, że zebrane przez Nieźychowskiego dzieła dotyczą kilku wybranych dziedzin, świadczy o planowym, a nie przypadkowym ich kompletowaniu. Ponadto wśród książek wymienione zostały „Listy pisane różne" i „Papier oprawny do pisania” oraz kilka piórników ${ }^{83}$. Pomocą w czytaniu i pisaniu służyło z pewnością "szkiełko do oczów"s", będące zapewne lupą lub okularami.

Kolejną interesującą pozycję stanowią 3 pularety ( $w$ tym jeden ze skóry czarnej z zamkiem $)^{\text {s5 }}$, czyli portfele. Co ciekawe, pomimo wzmianki o pularetach, inwentarz nie wymienia pieniędzy w gotówce.

\section{NACZYNIA I SZTUĆCE}

Naczynia i sztućce stanowią bardzo liczną grupę przedmiotów w inwentarzu. Największą wartość miało zapewne kilkanaście importowanych przedmiotów porcelanowych, wówczas bardzo cenionych, które w owym czasie razem z fajansem wypieraly cynę ${ }^{86}$. Przedmioty porcelanowe zajmują reprezentacyjne miejsca częściej niż np. cynowe. Składaly się na nie: lichtarze, czarki, tygle, wazy, kubki, różne figurki ozdobne i serwis do kawy. Porcelana pochodziła między innymi $z$ Wiednia i Saksonii ${ }^{87}$. Były też naczynia farfurowe: misy, półmiski, dzbanki ${ }^{88}$. Cenne były też szllane naczynia (szklanki, talerze, flaszeczki, czary, maselnice,

\footnotetext{
*a.k. 472 .

${ }^{81}$ Z. Libera, Wiek oświecony. Studia i szkice $z$ dziejów i literatury i kultury polskiej XVIII i początków XIX wieku, Warszawa 1986, s. 119, 123-124, 128-129.

${ }^{32}$ J. Dumanowski, Fuzje, jamniki..., s.87.

${ }^{83}$ APP, Wschowa, gr. 224, k. 477-478.

${ }^{84}$ Ibidem, k. 479 .

${ }^{85}$ Ibidem, k. 478.

${ }^{86}$ J. St. Bystroń, Dzieje abyczajów..., T. II, s. 421, 423.

${ }^{87}$ APP, Wschowa, gr. 224, k. 471-472, 480.

${ }^{88}$ Ibidem, k. 479.
} 
solniczki), tym bardziej, że niektóre $\mathrm{z}$ nich były pozłacane, lub zostały opatrzone herbem ${ }^{89}$. W kuchni znajdowały się cynowe, miedziane i żelazne tarki, durszlaki, brytfanny, moździerze, półmiski i tacki ${ }^{90}$.

Dużo było naczyń, sztućców oraz lichtarzy metalowych: srebrnych, „prynzmetalowych", miedzianych, mosiężnych i cynowych. Do posiłków można było podać dwanaście noży srebrnych i tyleż par takich łyżek, lub sztućce „prynzmetalowe" ${ }^{\text {"gil }}$. Fakt posiadania srebrnych sztućców dla kilkunastu osób jest wyznacznikiem wysokiego poziomu zamożności ${ }^{92}$. Jednak w przypadku dużej części naczyń i sztućców niemożliwa jest dokładna identyfikacja materiału z jakiego zostały wykonane, rejestr tego nie precyzuje.

\section{KAWA, TABAKA, TYTON}

Zwyczaj picia kawy napłynął do Polski i rozpowszechnif się w XVIII wieku. Na wprowadzenie tego zwyczaju oddziaływał zarówno Wschód, jak i Zachód”3. O spożywaniu tej używki świadczą wymienione w inwentarzu przedmioty: "garnitur do kawy porcelanowy saski" oraz lyżeczki do kawy, mlynek do kawy i trzy imbryki ${ }^{94}$. Cztery cynowe angielskie tabakierki wiązały się z zażywaniem tabaki. Oprócz tego w inwentarzu wymieniono blaszane, okrągłe pudełko do tytoniu z zamkiem mosiężnym oraz worek do tytoniu" ${ }^{95}$. Te dwa przykłady świadczą o używaniu tytoniu, na który moda rozpoczęła się wcześniej niż w przypadku kawy, bo już w XVII wieku ${ }^{56}$. O stosowaniu przypraw przy przyrządzaniu posiłków świadczą: „szkatułka do korzenia” oraz "młynek do pieprzu mielenia"

\section{ROZRYWKA - GRY}

Na podstawie inwentarza możemy także wysnuć wnioski na temat gier, którymi Nieżychowski i domownicy wypełniali wolny czas. Rozrywce służyly karty oraz szachy. Spis wymienia dwie drewniane tacki do gry w karty i szachownice $z$ drewna śliwkowego, wyzłacaną ${ }^{98}$. Gra w karty była w ówczesnej Rzeczypospolitej dość popularną formą rozrywki, inaczej było z szachami, które miały nieco elitarny charakter, znacznie popularniejsze od nich były warcaby ${ }^{99}$.

\footnotetext{
${ }^{89}$ Ibidem, k. 477, 479-481.

${ }^{90}$ Ibidem, k. 473.

${ }^{9}$ Ibidem, k. 477.

${ }^{92}$ A. Pośpiech, Srebrna lyzka .., s. 154-155.

${ }^{93}$ J. St. Bystroń, Dzieje obyczajów..., T. II, s. 504.

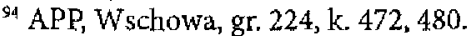

${ }^{95}$ Ibidem, k. 479.

96 J. St. Bystroń, Dzieje obyczajów.., T. II, s. 507-509.

${ }^{97}$ APP, Wschowa, gr. 224, k. 473, 481.

${ }^{98}$ Ibidem, k. 479, 481 .

${ }^{99}$ J. St. Bystroń, Dzieje obyczajów..., T. II, s. 204-205, 211-212.
} 


\section{POIAZDY}

Inwentarz wymieniający wyposażenie stajni w folwarku w Długich Starych wspomina między innymi o pojazdach ${ }^{100}$. Część z nich miała zastosowanie w gospodarstwie: taczka, wóz i wózek, oraz sanki do zwożenia drzewa. Kolejne trzy pojazdy należą już do kategorii paradnych. Są to dwie karety, jedna półtoraroczna, na cztery osoby, wybita czerwonym suknem, druga przeznaczona dla dwóch osób, wybita czerwoną trypą (półwełnianą tkaniną produkowaną w Gdańsku, jest prawdopodobne, że ta kareta pochodzila wlaśnie z Gdańska ${ }^{101}$ ). Mianem karety określano zamknięte pojazdy paradne dwu lub czteroosobowe. Mialy one cztery koła i były zawieszone na pasach ${ }^{102}$. W spisie wymieniony jest również częściowo przykryty powóz na cztery osoby, wybity zielonym suknem. Adnotacja informuje, że należał on do wdowy. Określenie powozu jest wieloznaczne, jednak z pewnością odnosi się do pojazdu eleganckiego. Komunikacji w zimie służyły saneczki jednoosobowe i drewniane sanie dwuosobowe. Były one zwykle drewniane i rzeźbione ${ }^{\mathrm{in3}}$.

Także w stajni znajdowały się cztery konie cugowe, czyli przeznaczone do zaprzęgu (co nie było dużą ilością) ${ }^{104}$. Posiadano do nich ponadto potrzebne wyposażenie. Byly to cztery dery, cugle, siodło oraz uździenice ${ }^{105}$.

Za środek transportu należy uznać stojącą w sieni dworu lektykę, służącą do noszenia wdowy do kościoła ${ }^{106}$. Lektyki słuzyły do przenoszenia jednej osoby na niewielkie odległości. Noszono w nich osoby starsze, chore lub po prostu kapryśne. Przechowywano je, tak jak w tym wypadku, w sieni. Ich rozpowszechnienie było związane $\mathrm{z}$ modą na chińszczyznę, która pojawiła się $\mathrm{w}$ Polsce $w$ latach 70-tych XVIII wieku ${ }^{107}$.

\section{INNE PRZEDMIOTY}

Wśród mebli na uwagę zasługują cztery drewniane zegary ${ }^{108}$. W codziennych obowiązkach pomocne były dwa biurka, jedno $z$ nich, saskie, należało do wdo$w^{109}$. Inwentarz wspomina także o lustrach. Zwierciadła znajdowały się głównie w izbach, w których podejmowano gości. Razem było ich aż szesnaście. Jedno $z$ nich bylo nawet opatrzone herbem Nieżychowskiego i cyfrą jego żony ${ }^{110}$.

${ }^{100}$ APP, Wschowa, gr. 224, k. 483.

101 J. Kitowicz, Opis obyczajów..., s. 273; T.Żurawska, Polskie powozy, Wrocław-Warszawa-Kraków-Gdańsk-Ł́ódź 1982, s. 225.

102. T. Zurawska, Polskie powozy..., s. 221.

103 Ibidern, s. 119.

${ }^{104}$ J. St. Bystron, Dzieje obyczajów.., T. II, s, 528.

105 APP, Wschowa, gr. 224, k. 482-483.

106 Ibidem, k. 470.

${ }^{107}$ T. Zurawska, Polskie powozy.., s. 124-125.

${ }^{108}$ APP, Wschowa, gr. 224, k. 476-477.

${ }^{109}$ Ibidem, k. 471 .

110 Ibidem, k, 471-472, 476 . 
Zaskakujące jest odnalezienie w spisie dwóch barometró $w^{111}$. Na tej podstawie trudno wysnuwać jakieś wnioski odnośnie zainteresowań Nieżychowskiego. Nie wiemy oczywiście, czy domownicy potrafili się nimi posługiwać, jednak ich obecność może sugerować na zamiłowanie do nowości, może być też interpretowana jako probierz zamożności, podobnie jak zegary i zwierciadła. Podobnie zastanawiająca jest „waga do ważenia złota $\mathrm{z}$ kamieniami" ${ }^{112}$.

\section{RUCHOMOSCI POCHODZENIA WSCHODNIEGO I ZACHODNIEGO}

W epoce nowożytnej Rzeczpospolita znajdowała się w kręgu oddziaływania kultury wschodniej, orientalnej, wyrażającej się najpełniej w sarmatyzmie oraz kultury zachodniej - niemieckiej i francuskiej. Ten specyficzny charakter polskiej kultury szlacheckiej znajdował odzwierciedlenie w przedmiotach materialnych. Sądzę, że można pokusić się o ustalenie pochodzenia choćby części ruchomości, chociaż często inwentarze zawierają błędne i nieścisłe informacje na ten temat ${ }^{113}$.

Pierwszy przedmiot, o określonej proweniencji, to należące do wdowy biuro orzechowe przywiezione przez męża $z$ Drezna ${ }^{134}$. Z Francji, jak można przypuszczać, pochodziły kopersztychowe obrazy $z$ francuskimi wierszami ${ }^{115}$. Serwis do kawy został opisany jako pochodzący z Saksonii ${ }^{116}$. Jak już wyżej wspomniałem, ubiory Nieżychowskiego także pozostawały pod wpływem mody zachodniej. Nie wiemy, gdzie zostały uszyte, jednak w przypadku jednej z sukni material jest określony jako holenderski, a jeden $z$ szlafroków opisano jako niemiecki. Ponadto w rejestrze wspomniano o „Manszestrze”, zapewne chodzi o materiał pochodzący $z$ Manchesteru"117. Z Anglii pochodzilo też osiem dużych mis cynowych, oraz cztery cynowe tabakierki ${ }^{118}$. Rodowód francuski miało żelazne łóźko ${ }^{119}$. Do przed * miotów pochodzących z zachodu wypada zaliczyć również książki, przynajmniej te opisane jako niemieckie (co najmniej pięć) ${ }^{120}$.

Spis zawiera też przedmioty pochodzenia orientalnego, jednak tych jest znacznie mniej, niż pochodzących z zachodu. Są to tureckie makaty ${ }^{121}$, tureckie kobierce $^{122}$, tureckie obicia ${ }^{123}$, a nawet turecki namiot ${ }^{124}$.

"I Ibidem, k. 470, 476 .

112 Ibidem, k. 478 v.

${ }^{13} \mathrm{~J}$. Dumanowski, Orientalne i zachodnie wzory konsumpcji szlachty wielkopolskiej $w$ XVI-XVIII wieku, [w:] Między Zachodem a Wschodem: Studia $z$ dziejow Rzeczypospolitej w epoce nowożytnej, pod red. J. Staszewskiego, K. Mikulskiego i I. Dumanowskiego, Toruń 2002, s. 153-154.

${ }^{114}$ APP, Wschowa, gr. 224, k. 471.

115 Ibidem, $\mathrm{k} 471$.

116 Ibidem, k. 472.

${ }^{117}$ Ibidem, k. 474-475.

${ }^{118}$ Ibidem, k. 477, 479.

${ }^{119}$ Ibidem, k. 478.

${ }^{120}$ Ibidern, k. 477-478.

121 Ibidem, k. 475.

122 Ibidem, k. 476.

${ }^{123}$ Ibidem, k. 481.

${ }^{124}$ Ibidem, k. 480. 
Wśród przedmiotów, których pochodzenie zostało określone w inwentarzu, zdecydowanie przeważają te wywodzące się zachodu (niemieckie - głównie saksońskie, angielskie, francuskie i holenderskie). Chciałbym zwrócić uwagę, że mobilia o zachodniej proweniencji zostały przypuszczalnie zakupione niedawno (np. biurko, ubrania, porcelana), natomiast przedmioty orientalne mogły być odziedziczone po przodkach, $z$ czasów gdy wśród szlachty powszechnie panowała kultura sarmacka. Na XVIII wiek przypada okres największych wpływów francuskich (i niemieckich) w Rzeczypospolitej. Przewaga przedmiotów pochodzących z zachodu i noszenie przez Nieżychowskiego francuskiego stroju dowodzi, że ulegał on zachodnim wzorcom w zakresie konsumpcji. Uleganie modom i nowoczesności jest tutaj oznaką pozycji społecznej i ekonomicznej właściciela tych dóbr ${ }^{125}$. Ponadto posiadanie przedmiotów z zachodu (szczegónie chodzi tu o Saksonię) potwierdza utrzymywanie kontaktów z zagranicą, między innymi z drezdeńskim dworem.

\section{PRZEDMIOTY ODZIEDZICZONE PO PRZODKACH}

Każdy inwentarz zawiera przedmioty odziedziczone po przodkach i nabyte przez współczesnych. W spisie odnajdujemy bardzo mało wzmianek o przedmiotach odziedziczonych, zwykle nie rozróżniano tego, co dawne, od tego, co współczesne. Jest jednak oczywiste, że znaczna część mobiliów musiała pochodzić od przodków. Wskazówką, choć niezbyt pewną, może być opisanie przedmiotów jako stare. Do tej kategorii należały bezsprzecznie dwie stare karety wdowy (wymienione potem przez nią na powóz). Ludwika Nieżychowska odziedziczyła je po „księdzu kanoniku Jabłonowskim" ${ }^{\text {"25 }}$. Chodzi tu o Hilarego - kanonika płockiego lub Jacentego -- kanonika i proboszcza żółkiewskiego. Obydwaj byli braćmi ojca Ludwiki, Mikołaja ${ }^{127}$.

\section{PRZEDMIOTY NALEŻACE DO WDOWY}

Wdowa spisując inwentarz nie omieszkała zaznaczyć, które z dóbr materialnych należą do niej. Ta dbałość wynikała $z$ obawy o własny majątek po śmierci męża, gdyż ten należący do zmarłego dziedziczyli spadkobiercy $z$ jego rodziny, względnie dzieci. Należało więc zastrzec, które mobilia do męża nie należały. Sytuacja taka była zresztą bardzo powszechna, bo to wdowy zwykle sporządzały takie rejestry ${ }^{128}$. Inwentarz nie wymienia ubrań wdowy, zapewne było oczywiste, że stanowify one jej własność. W sieni dworu znajdowała się lektyka służąca do noszenia wdowy do kościoła oraz skrzynia wielka i wysoka do chowania rzeczy wdowy ${ }^{129}$. W pierwszym pokoju przedmiotami wdowy były: relikwiarz, stół oraz

${ }^{125}$ J. St. Bystroń, Dzieje obyczajów..., T. I, s. 99; A. Pośpiech, Pulapka oczywistości..., s. 91.

${ }^{126}$ APP, Wschowa, gr. 224, k. 483.

${ }_{127}$ A. Boniecki, Herbarz polski, T. VIII, Warszawa 1905, s. 115.

${ }^{128}$ E. Balcerzak, Nie ciesz się przed czasem, czyli wątpliwa wartoś́ spadków, [w:] Nędza i dostatek..., s. 85; A. Pośpiech, Pulapka oczywistási..., s. 54-55, 62.

${ }^{129}$ APP, Wschowa, gr. 224, k. 470. 
niektóre meble, w tym podarowane przez męża biuro (biurko) orzechowe z Drezna. W drugim pokoju własnością wdowy były meble, porcelanowe naczynia, obrazy ${ }^{130}$. Płócienne łóżko wdowy znajdowało się w trzecim pokoju, a komoda $z$ jej bielizną $w$ gabinecie $^{131}$. Do wdowy należał także malowany parawan, jeden koń i jeden powóz częściowo przykryty, czteroosobowy, wybity zielonym suknem. Został on wymieniony za dwie stare karety ${ }^{132}$, które Ludwika Nieżychowska odziedziczyła po „księdzu kanoniku Jabłonowskim”'133.

\section{PODSUMOWANIE}

Kończąc niniejsze opracowanie należy stwierdzić, że obraz Ignacego Nieżychowskiego, jaki znamy $z$ opracowań, dotyczący jego pozycji majątkowej, dziatalności politycznej i wyznania jest zgodny $z$ tym, co prezentuje inwentarz. Zaangażowanie polityczne po stronie ugrupowania dworskiego znajduje wyraz w uleganiu zachodniej modzie, szczególnie w zakresie ubioru, ale nie tylko. Posiadanie obrazów świętych i innych związanych z religijnością przedmiotów oraz dary na Kościól potwierdzają katolickie wyznanie Nieżychowskiego i jego żony. Jeśli zaś chodzi o status ekonomiczny możemy stwierdzić, że zawartość inwentarza współgra $z$ faktem posiadania dziewięciu wsi i sprawowaniem podkomorstwa. Jedyne, co może budzić zdziwienie, to wspomniany brak pieniędzy w gotówce i biżuterii ${ }^{134}$. W inwentarzu nie ma żadnego zapisu na temat gotówki, co wcale nie oznacza, że jej nie było, jednak w powiązaniu $\mathrm{z}$ adnotacją o zaciągnięciu pożyczki pod zastaw czterech "makatów tureckich" ${ }^{135}$, może świadczyć o klopotach finansowych Nieżychowskiego. Ten przykład zdaje się potwierdzać trudności finansowe szlachty, która pomimo posiadania wielu wsi, nie miała pieniędzy i biżuteriii ${ }^{356}$. $\mathrm{Z}$ drugiej strony właściciel kilku folwarków musiał obracać w tym czasie dużymi sumami pieniędzy. Na przykład w 1783 roku (5 lat po śmierci Nieżychowskiego, wcześniejszych danych nie posiadamy) dochód z dóbr Długie Małe wynosił ponad $2000 \mathrm{z}$, a roczny obrót ponad $2500 \mathrm{z}^{137}$.

Inwentarz pozwolił na poznanie dworu $\mathrm{z}$ jego poszczególnymi pomieszczeniami, ich wyposażeniem i przeznaczeniem. Dostarczył informacji nie tylko na temat statusu finansowego właściciela mobiliów. Zaprezentował nam takźe postać człowieka będącego pod wpływem oświecenia, posiadającego książki i mapy, a więc mającego zainteresowania intelektualne. Wiele z przedmiotów wymienio-

\footnotetext{
${ }^{139}$ Ibidem, k. 471.

131 ibidem, k. 472.

${ }^{132}$ lbidem, k. 474, 482 -483 .

${ }^{133}$ Ibidem, k. 483.
}

${ }^{134}$ W końcu XVIII wieku biżuteria pojawia się $w$ inwentarzach rzadziej niż w pierwszej jego połowie. Por. J. Dumanowski, Inwentarze wielmożnych..., s. 271.

${ }^{135}$ "Makatów tureckich 4 ltóre w zastawie ut Imća pana Andrzeja Moraczewskiego", k. 475.

${ }^{136}$ St. Życiński, Kosztowności $w$ inwentarzach pośmiertnych szlachty koronnej $w$ dobie sarmatyzmu. Wyznacznik zróżnicowania majatkowego, [w:] Nedza i dostatek.., s. 172

${ }^{137}$ Dzieje Wielkopolski, T. I do roku 1795, pod red J. Topolskiego, Poznań 1969, s. 823; J. Topolski, Wielkopolska poprzez wieki, Poznań 1999, s. 130. 
nych w inwentarzu stanowiło w owym czasie rzadkość (obrazy, książki, kopersztychy, zegary), a nawet absolutny unikat (atlasy, mapy, barometry) i wyróżniają inwentarz Nieżychowskiego spośród innych spisów mobiliów tej epoki. Z drugiej strony inne spisane w nim przedmioty, takie jak odzież typu zachodniego oraz meble, są powszechne i stosunkowo często spotykane wśród szlachty w końcu XVIII wieku ${ }^{138}$. Chcę też zauważyć, że w inwentarzu znajduje odzwierciedlenie zjawisko wypierania przedmiotów starych, dawnych i odziedziczonych po szlachetnie urodzonych przodkach (a więc potwierdzających przynależność do mającego swoją historię rodu), przez przedmioty nowe, prezentujące zachodni typ konsumpcii, które wśród szlachty upowszechniają się w drugiej połowie XVIII wieku. Ich rolą nie było już potwierdzenie istnienia „wielmożnych" lub „urodzonych" przodków, lecz raczej udowodnienie, że posiadają odpowiednie możliwości ich nabycia i nadążają za modą i nowościami. Do pierwszej kategorii przedmiotów „wypieranych" należą: strój narodowy i kojarzona $z$ nim broń biała i srebra. Do drugiej kategorii zdobywającej popularność zalicza się ubiór zachodni, porcelanę, przedmioty związane ze spożywaniem kawy, herbaty i czekolady ${ }^{139}$. W przypadku opisanego inwentarza tendencja ta zostaje potwierdzona. Ignàcy Nieżychowski ulegał zachodnim wzorcom konsumpcji, oddalając się nieco od sarmackiej tradycji.

Podkomorzy wschowski bez wątpienia należał do elity regionu. Dla innych przedstawicieli stanu szlacheckiego stanowił wzor do naśladowania. Abstrahując od jego działalności politycznej i katolickiego wyznania, należy stwierdzić, że nie ma on już wiele wspólnego $z$ powszechnie spotykanym wcześniej wizerunkiem szlachcica-sarmaty. Ubiera się według zachodnich wzorców, jest więc „elegantem". Podróżuje i bywa w świecie, jest oczytany, rozwija własne zainteresowania. Na jego przykładzie widać więc następującą zmianę epoki - idee Oświecenia znajdują odzwierciedlenie w jego stylu życia, kulturze i poziomie intelektualnym.

${ }^{138} \mathrm{~J}$. Dumanowski, Inwentarze wielmożnych..., s. 268, 271, 273-274.

${ }^{139}$ Ibidem, s. 269-271, 274. 